\title{
Neo-Confederates Take Their Stand: Southern Agrarians and the Civil War Niall Munro
}

Recent events in the United States have brought the term 'neo-Confederate' abruptly into the public consciousness. Conflicts over Confederate statues and Confederate symbols, the killings at the Emanuel AME Church in Charleston, and the 'Unite the Right' rally in Charlottesville, Virginia which resulted in the death of counter-protestor Heather Heyer indicate that neo-Confederate activity has increased as result of the increasingly frequent melding together of neo-Confederate, white nationalist, and white supremacist interests. Even if it has a rather different emphasis now, the term 'neo-Confederate' is plainly not new and can be traced all the way back to the 1890s, with moments of notable re-emergence in the twentieth century when white supremacy or Southern identity were perceived to be under threat. Euan Hague, Edward H. Sebesta, and Heidi Beirich have argued that a new strain of neo-Confederate thought emerged in the 1990s, which, as they put it, was a movement in US political culture that 'fus[ed] separatism, nationalism, Confederate heritage, and a politics that looked through a lens of race and ethnic identity' (2007: 7).

In this article, I explore another line of neo-Confederate thought, the Southern Agrarian modernist manifesto I'll Take My Stand: The South and the Agrarian Tradition and set it against the major poetry of two of its key authors, Allen Tate and Donald Davidson to explore how the Civil War profoundly affected their writing and thought. Even though the manifesto appeared some ninety years ago, its legacy has been profound. Andrew Hook notes that although it 'almost certainly changed nothing in the 1930s South', it 'remains a provocative work' (2004: 433-434). Indeed, Paul V. Murphy has demonstrated how the Agrarians exerted influence over later writers and critics who embraced the ways that the Agrarians celebrated and promoted a Southern tradition in literature and culture and advocated for a certain lifestyle that often looked longingly back to the antebellum period. Murphy has detailed how contemporary conservatives and members of the political right have adopted the Agrarians as "proponents of a social order based on religion, opponents of a godless and untraditional leviathan state, critics of a rootless individualism, and above all, stout defenders of the South, which necessarily entails a defence of southern tradition, culture and values' (2001: 7). The Agrarians, particularly Tate, Davidson, and Robert Penn Warren, also kept themselves in the public eye by publishing a second book, contributing to commemorative publications, and through taking part in two major reunions - in 1956 and 1980 - keeping the memory of I'll Take My Stand alive. However, much of this focus was on 
what might be called neo-Agrarian thought that was anti-modern, anti-industrial, and proSouth, rather than an examination of the Agrarians' fascination with the Civil War and what it might mean to call the authors of the manifesto neo-Confederates.

The 'Twelve Southerners' who contributed to I'll Take My Stand (nine poets and writers, a political scientist, a historian, and a psychologist) famously argued that the industrialism imposed by the North on the South was deeply damaging, that it was a direct result of the Civil War, and that only a return to agrarian life and values could save the South and maintain its traditions. But this critical focus on the agrarian project as resistance to industrialism has somewhat obscured what Richard Gray has identified as 'the essayists' almost obsessive references to the Civil War'. Gray observed that this concern with the Civil War 'is hardly enough by itself [...] to act as a means of giving focus, shape, and some sort of direction to the book' (1997: 143-144). Whilst it is certainly true that the war did not exactly shape the volume, I would suggest that this obsession with the war was all-consuming for a number of these writers, and that it did provide a crucial and continuing point of reference for the planning and writing of the manifesto. Warren's engagement with the Civil War (most famously in his brilliant 1961 centennial essay The Legacy of the Civil War) is well known, but the Agrarians' discussion of the conflict in the 1920s and 30s extended beyond the manifesto, with a remarkable sequence of works being produced by the contributors to I'll Take My Stand. This included two histories of the South by Frank Lawrence Owsley: State Rights in the Confederacy (1925) and King Cotton Diplomacy (1931); four biographies of Civil War figures (and a further one by Tate that remained unfinished) that were published between 1928-31; three novels that appeared in the period 1934-1938; and several major poems by significant Southern literary figures associated with the Agrarians, including Tate, Davidson, and John Gould Fletcher, published between 1916 and the 1940s.

In their attempts to fundamentally remake Southern identity, the Agrarians always returned to the Civil War as a moment of disaster, and the war was an essential and fundamental starting point for Agrarian thought. Without the conflict as an inspiration for language, ideas, and as a model of resistance, the Agrarian movement would not have had the impact that it did. Contemporary critics of the Agrarians, most famously H. L. Mencken, suggested that the Agrarians were 'sufferers from nostalgic vapors', but the truth is much more complicated than that (1931: 380). In fact, the Agrarians' stated aim to return to the antebellum period is not so much a desire to bask in the glories of an old civilization, as it is to identify the point at which Southern society started to go wrong and begin all over again. 
Their project attempts to erode modernist ideas and modernity from within, utilising the modernist figure of the exile or the outsider (a position that Davidson maintained as late as 1959 as he described the Agrarians as 'deliberate exiles' ([1959] 1966: 15)). Yet this consciously anachronistic position also seeks, in Walter Benjamin's formulation, to 'explode' Southern history and undermine the Northern and modernist enthusiasm for 'progress' by embracing in their writing and thought historical simultaneity, belatedness, and failure. In their ferocious devotion to a certain understanding of the past - one that promotes a kind of historical telling which brings the past directly into the present - the Agrarians also attempt to radically distort the temporal shape of Civil War memory. As Michael O'Brien notes, the fact 'that Southerners were newly conscious of the past in the present [...] was scarcely a novel discovery in 1930', but during the later 1920s and early 1930s, the Agrarian project absorbed the thoughts and writings of several of these particular Southerners and made re-asserting the past an essential element in their efforts to re-orient the South's future direction (1988: 162). Crucially, I show here how underlying much of this rhetoric and ideology is a latent, often unstated commitment to violence, a commitment that pushes apparently polemical writing over the edge into something more radical and threatening. Whilst recent events in America have shown how obsession with the Civil War and the Confederacy can quickly lead to violent acts, even in the Agrarians' time critics could see how such rhetoric could be inflammatory. Given the overtones of white supremacy in the manifesto and other work by the Agrarians, it is hardly surprising that it was an African American author and critic who sharply drew attention to the risks of allowing what he called 'unhistoric history' to remain unchallenged. In a 1930 review, Sterling A. Brown identified works by the Agrarians as potentially very dangerous for the way in which they glorified the Southern cause and had 'a great bearing on the future of liberalism in America' (1930: 136). As I will go on to suggest, the kind of warning that Brown gave is one that must be heeded in our own time.

\section{The Young Confederates}

As Robert J. Cook and others have noted, the 1900s and 1910s were punctuated with flurries of interest in the Civil War, whether it was for the centennial of Lincoln's birth in 1909, or the release in 1915 of D. W. Griffith's hugely popular epic film Birth of a Nation, which purported to tell the 'truth' of Southern experience during and after the War, but presented a white supremacist and racist view of the South (2017: 125-134). It was increasingly the case, of course, that Civil War veterans were dying, and with them the last remnants of the living memories of the war were disappearing too, and this added urgency and poignancy to the 
commemoration events of the 1910s such as the famous Gettysburg reunion of veterans in 1913. But as the 1920s wore on, the Agrarians reignited the war against the North as they refuted writings such as H. L. Mencken's 1917 article 'The Sahara of the Bozart', which castigated the South for having no real creativity, or tried to demonstrate that events such as the 1925 Scopes 'Monkey' Trial of 1925 in Dayton, Tennessee, which made many Northerners (and Southerners) regard the South as a place of ignorance and backwardness, were not representative of the real South. For the Agrarians, this meant grappling with Southern history and a revisionist approach to the Civil War that could appeal to a national audience, but it also meant combatting what they saw as an unrepresentative and damaging view of the South from within.

Published on 12 November 1930, I'll Take My Stand was the result of this resistance, and as early as the first responses to it, the Agrarians were labelled neo-Confederates. Even prior to the manifesto's publication, George Fort Milton in Tennessee's Chattanooga News noted that ' $[\mathrm{t}] \mathrm{o}$ this group, friends who admire their conscientious casuistry but disagree in part at least with their conclusions, have given the name of "the Young Confederates", (1930). Soon after this, under the striking title of 'Lee, We Are Here!', the Macon Telegraph in Georgia commented that '[o]ne of the strangest groups to flourish in the South is the neoConfederates' whose members, the Telegraph surmised, 'have seen the shadows of the smoke stacks and have become as alarmed as ever did a Kluxer at the sight of a healthybodied Negro' (1930). But such attacks were welcomed by the Agrarians since they aimed, as a group to be combative and to position themselves as distinctly different to the dominant voices in the North and South. Indeed, throughout their manifesto and in their other work, the Agrarians present the Southerner as an outsider in the United States, and they sought to cultivate this image as a badge of honour and genuine 'Southernness' and as a figure of resistance to Northern 'oppression' which they saw as continuing from the Civil War to the present.

\section{The Southerner as outsider and anachronism}

In his essay for I'll Take My Stand, 'Reconstructed but Unregenerate', John Crowe Ransom described himself as an 'unreconstructed Southerner', drawing upon language from the 1860s and 1870 s to position himself as someone who, like those Southerners who continued to resist Northern control during the Reconstruction period after the Civil War, refused to subscribe to what they saw as Northern oppression. In the 1860 s and 70 s, the unreconstructed Southerner resisted the idea that the South had lost, the notion that the North could now 
impose a different way of life upon Southerners, and the idea that African Americans were no longer slaves. In the 1930s, Ransom argued, the unreconstructed Southerner

persists in his regard for a certain terrain, a certain history, and a certain inherited way of living. He is punished as his crime deserves. He feels himself in the American scene as an anachronism, and knows he is felt by his neighbors as a reproach. ([1930] 2006: 1)

Both Davidson and Tate adopt and develop this role of the Southerner-as-outsider in their most famous poems: 'Lee in the Mountains' and 'Ode to the Confederate Dead'. Davidson's poem, written between 1933-34, soon after I'll Take My Stand, describes Robert E. Lee's post-war life between 1865-1870 when he was President of Washington College in Lexington, southwest Virginia. The piece is a dramatic monologue spoken by the former Confederate general that gives us a real sense of a man detached from his historical importance, exhausted, and an outcast:

Walking into the shadows, walking alone

Where the sun falls through the ruined boughs of locusts

Up to the president's office.... ([1934] 1966: 43)

There is some irony here in Lee entering 'the president's office', given that this former rebel fought to overthrow the president of the United States. Such imagery also makes clear the insignificance in which Lee now lives, just as the locust-covered trees act as a metaphor for the South in disarray, ravaged by war. Lee encounters some students on his way through the campus, and their respectful whispering and his reflections about them show how, by referring to them as 'boys' who speak to him as 'General Lee', he is blurring the lines between his memories of war and his life now at the college. As Elizabeth Brown Pryor has explained, '[a] large proportion [of the students] were Confederate veterans, for whom the general was as much legend as man, and, clad in his old army coat, he was indeed an éminence grise on campus' (2007: 438). But Lee always returns to the bitter truth:

It is not General Lee, young men...

It is Robert Lee in a dark civilian suit who walks,

An outlaw fumbling for the latch, a voice 
Commanding in a dream where no flag flies. ([1934] 1966: 43)

Lee seems to occupy the position of 'an anachronism' that Ransom discussed. Detached even from himself, Lee is an 'outlaw', which indicates he has become (according at least to Davidson) a kind of criminal or fugitive, recalling Ransom's description of the 'unreconstructed Southerner' as someone guilty of a crime. But the image of the outsider is also present in Allen Tate's poem 'Ode to the Confederate Dead', which he initially composed in 1926-27, prior to the writing and publication of I'll Take My Stand, and then revised at numerous points over the next twenty years. In the 'Ode', Tate describes a Southerner standing at the gate of a cemetery reflecting on his relationship to the dead men who lie interred there.

Autumn is desolation in the plot

Of a thousand acres where these memories grow

From the inexhaustible bodies that are not

Dead, but feed the grass row after rich row. ([1937] 2007: 20)

Here, the man is very much an anachronism, and like both Ransom's 'unreconstructed Southerner' and Davidson's Lee, he occupies a place of memory and reflection that is outside time and space. His lived experience of standing at the gate puts him in touch with the memories of the dead, or more specifically collective memories of the South that serve to bring the dead back to life, albeit as '[d]emons out of the earth' who 'will not last' ([1937] 2007: 21). This simultaneous sense of involvement in the past but also detachment from it is encapsulated in Maurice Halbwachs's conception of collective memory when he notes how 'the mind reconstructs its memories under the pressure of society', and argues that

the cult of the past, far from binding the hearts of people to society, in fact detaches them: there is nothing more opposed to the interest of society [...]. [T]hey are obliged to adjust to the only real world - the one in which they now live. They look back only intermittently at vanished time and they never linger there for long. ([1941] 1992: 51)

The kind of unique, collective, Southern memory that Tate is describing actually goes beyond what Halbwachs conceived. It is indeed a 'cult of the past', but in the cult of the Lost Cause that rewrites history and imposes a celebratory narrative upon the Civil War defeat of the 
South, the Agrarians and like-minded Southerners resist a notion about the past that tells them that they cannot 'linger there for long'. On the contrary, Tate and the Agrarians recognise the need for, and embrace, a preoccupation with the past that totally rejects a societal demand to constantly look forward. They are - as Halbwachs suggests - 'opposed to the interest of society', where 'a society' is a Northern-dominated, industrialised way of living and thinking.

\section{The Agrarian resistance to progress}

For Tate, Davidson and Ransom in particular, to consider the Civil War and Reconstruction past was to acknowledge the way in which Southern voices had been silenced, and the Agrarians' use and manipulation of the past and memory of the war was a form of resistance. In Thesis XIV of his 'Theses on the Philosophy of History' (1940), Walter Benjamin described how '[h]istory is the subject of a structure whose site is not homogeneous, empty time, but time filled by the presence of the now [Jetztzeit]' ([1940] 1999: 253). As Benjamin scholars have made clear, Benjamin was talking about a Jewish mystical conception of 'now', but the idea that the past and present can be blurred in the presentation of history is a crucial way of understanding the Agrarian reaction to the Civil War era. This is not as straightforward as saying simply that the past affects the way we think in the present. Rather it implies that, as Benjamin writes in his Thesis $\mathrm{XV}$, a group of people can embrace a past so fiercely that they 'make the continuum of history explode' ([1940] 1999: 253). For Benjamin, this is how revolutionaries behave - figures like Robespierre, who saw the French Revolution as bringing ancient Rome once more into existence. The Agrarians in I'll Take My Stand saw themselves as just such another revolutionary group, their manifesto and other writings advocating a return to the attitudes and practices of an antebellum period which they regarded as one of great civilization (and, as I will go on to suggest, their approach foreshadows the responses of more recent neo-Confederate groups who have often used Confederate symbols, especially flags and monuments, as focal points for the exploding of history). As will become clear, such interventions into historical time can create possibilities for social and political change, but it is also clear that they can also introduce dangerous instability and uncertainty.

This kind of radical historical thinking dismantles the idea that past/present/future are distinct periods and suggests not only that revision of that history is possible and desirable (in the Agrarians' pro-Confederate biographies, for instance), but that it should inform the way a society develops. Summarising Benjamin's 'Theses', Jürgen Habermas suggests that '[t]he horizon open to the future, which is determined by expectations in the present, guides our 
access to the past' ([1985] 1987: 13). Not only are we never free from the past, Habermas indicates, but Benjamin is also showing how at times our thinking forward into the future can afford us insights into where we have come from. In his 'Ode', Tate contends with the same kinds of challenges: how can we restore our relationship to a past with which we may have lost touch, and how will our future negotiation of that past come to redefine our understanding of the present? Habermas continues in his analysis of Benjamin's 'Theses' to note that

[t]o all past epochs he ascribes a horizon of unfulfilled expectations, and to the futureoriented present he assigns the task of experiencing a corresponding past through remembering, in such a way that we can fulfil its expectations with our weak messianic power. ([1985] 1987: 14)

This describes the struggle with which Tate and the Agrarians are engaged: both the recognition that the Southern past was, in part, a failure, and that the way we remember can be experiential, as in Tate's use of a refrain in his 'Ode', which was intended to dramatise the struggle of the man at the gate to connect with the memory of the Confederate soldiers: he imagines leaves to be soldiers but also recognises that they are only leaves. Habermas's comments also fit the Agrarian philosophy in another way, as the writers frequently saw themselves charged with an obligation to fulfil certain 'expectations' of their forebears and to address the extent to which these expectations are 'unfulfilled' because of a failure on the part of those ancestors. As I will argue, Tate and his colleagues sought to reassess the notion of failure (encapsulated in the utter defeat in 1865) and to adopt the revisionist Southern view of the war that was the Lost Cause ideology. In the essay that concluded the collection, 'Not In Memoriam, But In Defense', Stark Young claimed that the Agrarians' work addressed 'a problem practical enough: the defense of what we have drawn not from theory but from an actual civilization, and believe it necessary to remember. For us there are certain things, now endangered, that leave a kind of death to follow after them, and so must not be lost' ([1930] 2006: 329). There is an urgency in Young's words that recall the protests - in the past and now - of heritage groups like the United Daughters of the Confederacy or Sons of the Confederate Veterans against the removal of Confederate monuments or, indeed, the resistance of certain states like Alabama and North Carolina to removing such memorials and their enactment of laws to preserve memory for 'patriotic reasons'. 
But the Agrarians are also deeply troubled in I'll Take My Stand about how far the modernist impulse is committed to progress or is 'future-oriented', and Habermas summarises this kind of concern when he uses Benjamin's ideas to explore the concept of 'anamnesis' - the recalling of something from the past.

The anamnestic redemption of an injustice, which cannot of course be undone but can at least be virtually reconciled through remembering, ties up the present with the communicative context of a universal historical solidarity. This anamnesis constitutes the decentering counterpoise to the dangerous concentration of responsibility that modern time-consciousness, oriented exclusively toward the future, has laid on the shoulders of a problematic present that has, as it were, been tied in knots. ([1985] 1987: 15-16)

The Agrarians made it their mission to contest at least some of this kind of understanding of history and memory. Habermas seems to understand the 'unfulfilled expectations' of the past as representing a form of injustice. For the Agrarians there was no doubt that they and the South had suffered multiple injustices at the hands of the North from the period of the Civil War to the present. They also felt deep historical solidarity with their ancestors, and as Tate's poem shows, that affinity is not without its challenges, since whilst it is true that 'memories grow', they are still derived from an 'immoderate past' that has a tendency to spill over and, in Benjamin's terms, risks making the 'then' the 'now' with potentially perilous results ([1937] 2007: 20-21). But Habermas's interpretation of Benjamin's 'Theses' here also allows us to further explore the question of what responsibilities present generations have to that past (and to the future). For the Agrarians, a 'future-oriented' present is bound up with certain Northern expectations that they do not share - as I have been suggesting, Ransom and the others pride themselves on taking on the role of 'an anachronism', and celebrate being someone 'felt by his neighbors as a reproach' or, to employ Habermas's term again, as someone who is at odds with the North over 'an injustice'. Indeed, the Agrarian project is in direct opposition to what some of its members understood as modernity's constant preoccupation with the future, represented for them in Northern talk of industrialism and assumptions of progress, and to which the Agrarian understanding and use of memory act as a 'decentering counterpoise'. At times in I'll Take My Stand, this also sounds like a complete rejection of a modernist aesthetic and philosophy. For instance, in his essay Ransom demands: 
Will the Southern establishment, the most substantial exhibit on this continent of a society of the European and historic order, be completely crumbled by the powerful acid of the Great Progressive Principle? Will there be no more looking backward but only looking forward? Is our New World to be dedicated forever to the doctrine of newness? ([1930] 2006: 20-21)

For many critics, Ransom's attack was consistent with the Agrarian broadsides against industrialism and a Northern conception of progress. But how much of this rejection of modern life and progress was truly meant and how much was rhetorical? In the cases of Ransom and Tate, the issue is complicated by the fact that, as Ransom indicates here, when they looked back, they were looking to a Southern civilization that modelled itself on European cultural values, not just American ones. What is more, when the Agrarians as a group looked back, did they really see what they thought they saw or what they imagined? The antebellum South that they championed was not, as Michael O'Brien has observed, as anti-modern as they claimed. 'Indeed', O'Brien remarks, 'it is arguable that the Southern economy in 1850 , before the decline of cotton, was more a part of the modernizing world than it was to become in 1920' (1988: 162). However, rather than re-tread ground that O’Brien, C. Vann Woodward, Daniel Joseph Singal, and Richard H. King have covered, I want instead to suggest that these writers' stated attempts to stall the machine of progress also represented a fervour both for failure itself and for how such failure might not just challenge modernist aesthetics but also promote a Southern way of life.

\section{Failure and the Lost Cause}

Tate described 'Ode to the Confederate Dead' as representing the 'failure of human personality to function objectively in nature and society' ([1938] 1970: 595-596). Writing this in 1938, perhaps Tate was reading Agrarian concerns with the land and politics back into a poem he started writing some years before I'll Take My Stand, but there is a clear link between his definition here and the manifesto, which grappled with the idea that human beings had lost touch with their relationship to nature and the understanding of what made up an agrarian society. But in the 'Ode', in Davidson's poems, and in I'll Take My Stand, the concern with failure occurs again and again to the point where it becomes a fixation. Even in a letter of June 1931 to John Peale Bishop, written just after the manifesto's publication (and 
not coincidentally during his writing of the soon-to-be-abandoned biography of Robert E. Lee), Tate continued to associate the South with failure:

The significance of the Southern way of life, in my time, is failure: those Southerners who leave their culture - and it is abandoned most fully by those who stay at home and succeed in some not too critical meaning of success, sacrifice some great part of their deepest heritage. What else is there for me but a complete acceptance of the idea of failure? (Young and Hindle (eds.) 1981: 34)

Rather than lament this yoking of the South to failure as Davidson does in his Lee poem, Tate's concern with 'the Southern way of life' calls for a reassessment of what 'failure' means; an identification with it as something usable in the Southern past. For Tate, it is an essential and intrinsic part of being Southern, and when he says that he is in 'complete acceptance' with the idea, he affirms it as a part of his identity. For a Southerner to enjoy some measure of what is recognised as success (and perhaps here Tate the writer is thinking of critical acclaim in the pages of the Northern literary magazines), would be to deny 'their deepest heritage', and that heritage represents the South's mythologisation of its greatest failure - its loss in the Civil War - because at the heart of it is the 'Lost Cause'.

With its traces particularly evident in the manifesto essays by Ransom, Davidson, Owsley, Tate, and Young, the Lost Cause had a history stretching back to immediately after the Civil War. David W. Blight neatly summarises it like this:

The Lost Cause took root in a Southern culture awash in an admixture of physical destruction, the psychological trauma of defeat, a Democratic Party resisting Reconstruction, racial violence, and with time, an abiding sentimentalism. On the broadest level, it came to represent a mood, or an attitude toward the past. It took hold in specific arguments, organizations, and rituals, and for many Southerners it became a natural extension of evangelical piety, a civil religion that helped them link their sense of loss to a Christian conception of history. (2001: 258)

Although Blight is referring to a period in the late nineteenth or early twentieth century, this mood or attitude is ever-present in I'll Take My Stand. For example, in his celebration of the unreconstructed Southerner, Ransom regretfully observes that ' $[\mathrm{h}]$ is fierce devotion is to a lost cause - though it grieves me that his contemporaries are so sure it is lost' ([1930]) 2006: 
2). Davidson meanwhile remarks in his essay, 'A Mirror for Artists', that people living in the South 'share a common past, which they are not likely to forget; for aside from having Civil War battlefields at their doorsteps, the Southern people have long cultivated a historical consciousness that permeates manners, localities, institutions, the very words and cadence of social intercourse' ([1930]) 2006: 53). Although the arguments of the Agrarian project seem to be focussed on the conflict between industrialism and agrarianism, behind all of this the Lost Cause lurks, and a commitment to promoting it - and a celebration of a certain understanding of failure - as an essential element of Southern culture. It is a commitment that is dramatized in Davidson's 'Lee in the Mountains'. On the one hand, the character of Lee describes his preoccupation in the last years of his life - an editing of and introduction to his father's memoirs, noting that '[h]e would have his say, but I shall not have mine', and so implying that Lee will have no further role in Southern affairs ([1934] 1966: 44). But as the poem progresses, we learn that Lee believes if were he to encourage it, the Lost Cause, merely smouldering, could burst once again into flame:

If it were said, as still it might be said -

If it were said, and a word should run like fire,

Like living fire into the roots of grass,

The sunken flag would kindle on wild hills,

The brooding hearts would waken, and the dream

Stir like a crippled phantom under the pines,

And this torn earth would quicken into shouting

Beneath the feet of ragged bands -

\section{The pen}

Turns to the waiting page, the sword

Bows to the rust that cankers and the silence. ([1934] 1966: 45)

This passage begins with wishful thinking; the Confederacy was utterly defeated in 1865 (even Ransom called it a defeat of 'remarkable decisiveness'), and there was no chance of a further uprising, but for Davidson and the Agrarians, such optimistic sentiments located so clearly in the Southern soil offered them a glorious opportunity ([1930] 2006: 21). Whereas in these final three lines Lee realizes the danger of undoing sectional reconciliation and turns back to his father's memoirs - a kind of 'retreat' that is also signified by Davidson's lineation - it is at this moment that the Agrarians seek to pick up the pen and wield it in the sacred 
cause. If Lee was not able to do it, if he could only use the pen to write about the past, then Davidson (and the Agrarians) might seize it to use as a weapon for a new kind of Southern future. It is no coincidence that this most passionate and dynamic part of the poem is the one that carries the greatest significance for Davidson and his belief in the ongoing Agrarian project, for the Agrarians sought to celebrate Lee and other Confederate figures and their values as inspiration for the South to rise again. As Charles Reagan Wilson has explained, '[a]t the heart of the religion of the Lost Cause were the Confederate heroes, who came to embody transcendent truths about the redemptive power of Southern society' ([1980] 2009: 10-11). Determining what form such redemption should take was an important unresolved question for the Agrarians in their planning of I'll Take My Stand and in the book itself. Subscribing to the Lost Cause religion, as Davidson did in 'Lee in the Mountains', was one way of adopting, as Wilson has suggested, 'an effort to overcome existential chaos, substituting a simplified, more comprehensible view of life for the ambiguities and contradictions that give rise to existentialism' ([1980] 2009: 16). In doing so, Wilson contends, Southerners 'have remembered their suffering and have cultivated the memory, in order to affirm that it was not meaningless' ([1980] 2009: 16). Even if it can only operate symbolically, religion, Wilson observes, can allow human beings to feel that they are in control of events. The fascination of the Agrarians with re-fighting the Civil War and embracing the Lost Cause in their writings can be partly explained by this desire to 'affirm that it was not meaningless' and to work out some of the frustration that they felt at not having been there in the 1860s (a form of nostalgia that I will discuss later). The result of this was often an assertion that something needed to be done, but at least in Tate's case, what this action might be and whether it could be achieved was not entirely clear.

For Tate, whose contribution to I'll Take My Stand was an essay called 'Remarks on the Southern Religion', the antebellum South had not 'possessed a sufficient faith in its own kind of God' ([1930]) 2006: 174). Tate concluded that the Southerner in 1930 who wanted to connect with his Tradition could not 'fall back upon his religion, simply because it was never articulated and organized for him', and must instead use political means 'to re-establish a private, self-contained, and essentially spiritual life' ([1930] 2006: 174-175). In fact, we might say that the Lost Cause, as a fusion of politics, culture, and religion - or as Wilson and Blight put it, a 'civil religion' - can be seen to have taken the place of organized religion for Tate and Davidson. But having advocated a political solution in place of a religious one as a way of grounding the Southerner in his heritage, Tate finishes his essay equivocally: 'I say that he must do this; but that remains to be seen' ([1930] 2006: 175). Perhaps Tate intended 
this final remark to act as a provocation. As we will see however, such ambiguity could prove dangerous.

From a literary perspective, Tate's response to Davidson's call to arms was complicated since it was grounded in a struggle between the values of the Old South as discussed at length in I'll Take My Stand, and the features of modernism to which Tate subscribed. When Ransom attacked progress in his essay, he sounded a note of caution, even frustration in those lines quoted above: 'Will there be no more looking backward but only looking forward? Is our New World to be dedicated forever to the doctrine of newness?' ([1930]) 2006: 20-21). This apparent resistance to one of modernism's self-proclaimed tenets was also a concern of Tate's, even though he was a great advocate for the 'new' poetry such as T. S. Eliot's The Waste Land - an advocacy through which, as Thomas A. Underwood has explained, he had previously come to verbal blows with Ransom in 1923 (2001: 81-82). But in a letter of January 1927 offering a critique of Tate's 'Ode' (later cited approvingly by Tate himself in his essay about the poem), Hart Crane wrote that the poem presented ' $[\mathrm{t}]$ he theme of chivalry - a tradition of excess (not literally excess, rather, active faith) which cannot be perpetuated in the fragmentary cosmos of today' ([1927] 1997: 307). In this comment, the condition of modernity actually renders the traditions of the Old South obsolete, and the Southerner, in this poem and elsewhere, finds himself once again an anachronism, to recall Ransom's phrase: not just out of time and place but more specifically subject to a kind of belatedness that is absolutely bound up with failure, the Lost Cause, and what it means to be Southern. It is the sense famously captured in William Faulkner's 1948 novel Intruder in the Dust, when Charles 'Chick' Mallison, reflecting on Southernness, remembers what his uncle used to tell him:

It's all now you see. Yesterday wont be over until tomorrow and tomorrow began ten thousand years ago. For every Southern boy fourteen years old, not once but whenever he wants it, there is the instant when it's still not yet two o'clock on that July afternoon in 1863 [...] and it's all in the balance, it hasn't happened yet, it hasn't even begun yet, it not only hasn't begun yet but there is still time for it not to begin against that position and those circumstances [...] yet it's going to begin, we all know that, we have come too far with too much at stake and that moment doesn't need even a fourteen-year-old boy to think This time. Maybe this time with all this much to lose than all this much to gain [...]. ([1948] 1964: 187-188, emphasis in original) 
Faulkner describes the moment in the Battle of Gettysburg in Pennsylvania prior to a disastrous Confederate attack known as Pickett's Charge that many Southerners - and some historians - believe marked the beginning of the end of the war for the Confederacy in 1863. He captures the romantic, sentimental notion to which Lost Causers might subscribe (and to recall Benjamin, 'time filled by the presence of the now'). Certainly, they argue, the charge that followed was deeply heroic, but if only that moment hadn't occurred, the Confederacy might have been saved, and things might have turned out very differently. But irrespective of whether this position is in any way supported by the facts, the problem is that it is always already too late. Davidson's 'Lee in the Mountains' even suggests a mystic or spiritual side or divine purpose to the Lost Cause (akin to the identification of it as a 'civil religion') when Lee remarks that 'God too late/Unseals to certain eyes the drift of time and the hopes of men and a sacred cause' ([1934] 1966: 44). Formally, the constant repetition of words and phrases in this poem, something that is even more pronounced in Tate's 'Ode', signals not only a reflective mood and an engagement with memory and recollection, but also echoes that moment in Faulkner's novel: 'This time. Maybe this time'. There is a desperation for things to turn out differently, and such repetition indicates an attempt to replay events to bring about a different outcome.

In one way, this is how we conceive of disaster, and for many white Southerners in particular there was no greater disaster than defeat in the Civil War. As Maurice Blanchot has written:

There is no reaching the disaster. Out of reach is he whom it threatens, whether from afar or close up, it is impossible to say: the infiniteness of the threat has in some way broken every limit. We are on the edge of disaster without being able to situate it in the future: it is rather always already past, and yet we are on the edge or under the threat, all formulations which would imply the future. ([1980] 1995: 1)

It is this sense of simultaneity and temporal confusion that Tate's poem and the Lost Cause explore - simultaneously too late, yet always having that sense of disaster present. It represents a form of excess, a spilling over of time or what Tate calls 'the immoderate past'. As we have already seen, Tate explained that the 'Ode' is about solipsism, about how 'we create the world in the act of perceiving it' ([1938] 1970: 595), and that 'the poem [...] is a certain section of history made into experience, but only on this occasion, and on these terms' ([1938] 1970: 597). Tate's comment echoes that sense that the Lost Cause tradition 
represents resistance not just to the North but to modernity, since it struggles to survive in a modern society. If, as Charles Baudelaire suggested, modernity is 'the transient, the fleeting, the contingent', then there is nothing for the man at the gate to grasp, no way for him to experience the past (and the other half of Baudelaire's definition of art, 'the eternal and the immovable') ([1863] 2006: 403). Southern failure - as presented by the Agrarians and summed up in the Lost Cause ideology - is simultaneously an attempt to be in the moment but also to strive to go beyond it, or as Blanchot puts it, to have 'broken every limit', whilst also recognising the impossibility of doing this.

\section{The quickening of a tradition}

If Tate's poetry and writing suggested the difficulty of experiencing the past, off the page he still exhibited a romantic, nostalgic side. In 1927, a few months after writing his first version of 'Ode to the Confederate Dead', Tate, his wife Caroline Gordon, and Andrew Lytle (another one of the Twelve Southerners), set out for a research trip around the Civil War battlefields. Tate was writing his biography of Stonewall Jackson, and Lytle was about to begin a book about another Confederate general, Nathan Bedford Forrest. Robert Penn Warren, who himself was working on a biography of John Brown, joined them at the scene of Brown's final stand, Harper's Ferry. Many years later, Lytle described their visit to Gettysburg:

We stood behind the rail fence behind the cornfield through which the enemy charged at the crucial moment of the contest, as Lee referred to the war. Allen turned to me. 'Two thousand of the enemy fell here,' he said with lowered breath. Caroline laughed aloud. She had never seen such glee, she said, in two men's eyes. But it was not only glee. The intervening years had fallen away and the imagination surcharged by the heart revealed the action as if we had stood there. In action there is no past, only the moving present tense. I felt then, as I'm sure he did, a tradition and its history quickening. (1980: 8)

For Tate in particular, this must have marked a defining moment in his interrogation of the Southern past. After all his research into Jackson and the war, after situating a Southerner at a Confederate graveyard who can't quite access the past, this may have been the closest that Tate came to actually re-enacting the Civil War and to being in the 'now', that Faulkner described, thinking 'This time. Maybe this time'. Indeed, at the top of a draft of a 1963 talk he 
gave in Minnesota to commemorate the Battle of Gettysburg, Tate wrote: '(A More Appropriate Title Might Be "Personal Reminiscences of Gettysburg; for I have often felt that I was there")' (undated [1963]). Even acknowledging the distance in years, it is noticeable that Lytle emphasises how much Tate seems to dramatize or occupy the moment, with his 'lowered breath' and reference to 'the enemy' as if he really was - as he hoped, in his 1963 talk, he would have been - 'not behind the Confederate lines, but in them, up front' (1963: 34). Just as in his Minnesota talk, when he explicitly encouraged his listeners to join him on the field through their collective memory and imagination, Tate (and Lytle) found themselves in a moment that blurred past and present together. Lytle's description of 'the imagination surcharged by the heart' could have come directly out of Tate's 'Ode', which reflects on 'knowledge/Carried to the heart', and the knowledge that this moment grants Tate and Lytle is a revitalization of heritage and tradition, or another way of knowing history. This enthusiastic, visceral engagement with the past is also a nostalgic one - or, as Janelle L. Wilson has contended (following Tom Vanderbilt), 'displaced nostalgia', since it is a longing for a period which Tate and Lytle did not live through. As Wilson observes, '[n]ostalgia is, of course, created in the present, and thus the displaced nostalgia (as well as the myriad other examples of nostalgia that abound) can be viewed as a commentary on life in the present' (2014: 101). I will return to the importance of nostalgia in a moment, but Wilson's comment is a reminder that one of the reasons that Tate and the others exhibited this displaced nostalgia was because they were deeply dissatisfied with the times in which they lived. In his work that dealt with the Civil War, Tate found a way to vicariously live through a period of action in the mid-nineteenth century at a time when he recognised the opportunity and need to act but could not quite work out how best to do so.

But other, more troubling things, are being quickened here too. Gordon identifies in Tate's and Lytle's eyes what she calls 'such glee' as the two men contemplate and try to inhabit a scene where mass slaughter took place. If Lytle is right, and Tate was indeed experiencing 'a tradition and its history quickening', then this was a tradition based on the exaltation and exhilaration of violence. Three years after their trip, Tate would return to the question of how the South should engage with its tradition in his essay for I'll Take My Stand, at the end of which he asks: 'How may the Southerner take hold of his Tradition? The answer is, by violence' ([1930] 2006: 174). As Underwood notes, in a letter to John Gould Fletcher of 31 May 1933, Tate wrote: 'I didn't mean to imply external force - I mean only inner compulsion', but this statement was left largely and dangerously open in his essay (2000: 164). And not just here. The manifesto as a whole and accompanying works of this 
period are notable for their provocative and equivocal approach to certain key issues around violence, race, and action.

In a 1930 review of seven recent books about the South and the Civil War entitled 'Unhistoric History', African American writer Sterling A. Brown assessed the two biographies of Stonewall Jackson and Jefferson Davis by Tate and Warren's book on John Brown. 'These books seem to me [...] exceedingly dangerous', wrote Brown (1930: 136). He noted that:

Today the tradition of glorifying the South gains momentum. Certain evils of modern life furnish the impulse to an easy romantic escape in dreams to a pleasanter past. Young men of the South, keen of mind, having set themselves up as 'liberals,' after having learned the most advanced technique, now use that technique for the buttressing of ancient prejudices. (1930: 134)

Brown's comments, published just a few months before I'll Take My Stand, seem to be directed squarely at the manifesto and the Agrarians more generally, with his references to the 'evils of modern life' suggesting industrial practices and the '[y] oung men of the South, keen of mind' aimed at groups like the Agrarians coming out of universities. On the one hand, Brown is concerned that the Agrarian biographies pass themselves off as history, when in fact they use a method of "specious generalization, of damning with faint praise, of unwarranted suppression or heightening, of invective, of abuse, of undoubted partisanship under the guise of objectivity, of flagrant appeals to existing prejudices' (1930: 161). Brown seems to be detecting in the glut of pro-Southern, revisionist works that appeared during the late 1920s, a strategic impulse, or, as he puts it, 'the agreement in manner of these seven books is a grave sign' (1930: 161). In fact, to read the initial plans for the Agrarians' 'symposium' or 'Southern movement', is to confirm Brown's concerns that such books could have a damaging influence on the way that the Civil War era was remembered. Writing to Davidson on 10 August 1929, Tate advocated 'agitation' led by 'an academy of Southern positive reactionaries' who would devise a constitution that would include 'a complete social, philosophical, literary, economic, and religious system' (Fain and Young (eds.) 1974: 229, emphasis in original). Underlying this system or strategy, Brown suggests, is a framework of deception that is governed by a powerful but misleading use of language (perhaps what he means here by 'the most advanced technique'). For an African American critic like Brown, the ambiguity in these books dealing with slavery and its consequences gives licence to the 
perpetuation of such attitudes; the 'buttressing of ancient prejudices'. Brown would have found plenty in I'll Take My Stand to support his fears: in his essay, Ransom claimed that '[s]lavery was a feature monstrous enough in theory, but, more often than not, humane in practice' ([1930] 2006: 14), whilst Owsley argued in 'The Irrepressible Conflict' that after the Civil War, the South was 'turned over to the three millions of former slaves, some of whom could still remember the taste of human flesh and the bulk of them hardly three generations removed from cannibalism' ([1930] 2006: 62). Whilst the tone of white supremacy ran through the whole manifesto, it was rare for such an explicit and virulent expression of racism to emerge. Susan V. Donaldson has argued that

however self-consciously some of the Agrarians would try to abide by what U. B. Phillips would call 'the Central Theme of Southern History' - its determined whiteness - their essays were nonetheless haunted by the blackness they tried to eschew, by African American counter-narratives of the Civil War and Reconstruction, by the new discourse of the New Negro, and by the Great Migration itself, which threatened to remove from the region altogether those who had traditionally defined the category and boundaries of southern whiteness. (2006: xxix-xxx)

Certainly, as the selections from the essays by Ransom and Owsley prove, several of the Agrarians embraced all too enthusiastically a reinstatement of antebellum values if that meant ensuring that African Americans were relegated to a position hardly removed from slavery. Nevertheless, despite this keenness to maintain a 'determined whiteness' and an ideology in the manifesto befitting it, one of the flashpoints in the drafting of the book occurred when Warren produced his essay, 'The Briar Patch' - an uneasy defence of segregation - which Davidson in particular regarded as too liberal.

Brown was not the only critic to worry about the Agrarians' use of language and what it might really mean. In February 1936, Seward Collins, editor of The American Review, gave an interview to Grace Lumpkin for the pro-Communist FIGHT magazine, in which he identified himself clearly as a fascist and claimed that the Agrarians shared his economic aims and ideas (1936). As Paul V. Murphy has explained, The American Review, which gave significant amounts of space to essays by the Agrarians, was 'a forum for the voices of the antimodern Right in the 1930s, many of whom admired the medieval and royalist past of Europe, but some of whom appreciated modern experiments in corporatism and fascism' (2001: 71). Lumpkin finished her interview by suggesting that in the Agrarians, and other 
writers for The American Review and The Southern Review, 'there is the beginning of a group that is preparing the philosophical and moral shirt-front for Fascism' (1936: 75).

Tate wrote a stinging open letter to rebut these claims ('I am so deeply opposed to fascism that I should choose communism if it were the alternative'), and it, along with Lumpkin's reply, was published in The New Republic (1936: 75). Lumpkin's response, however, took apart some of Tate's defence by quoting relevant passages of I'll Take My Stand, including his notion that the Southerner should take hold of his tradition 'by violence'. To this, Lumpkin replied: 'Does Mussolini want more than to recapture Roman slave-owning traditions by violence?' She observed, in a similar way to Sterling Brown, that the manifesto featured 'a great deal of ambiguous and vague writing, as well as many contradictory statements', and that even if the statements she went on to quote about radical politics and the need to re-establish an antebellum style of life 'in themselves do not make you fascists [...then] they are the theoretical foundation of a reactionary movement.' In addition, Lumpkin concluded, '[a]ny kind of honest examination of the theoretical basis of fascism by you and your group should make you uncomfortable at the similarity' (1936: 76).

The risk that the Agrarians took - consciously or unconsciously, and I have been suggesting that much of this was conscious - was to leave themselves open to charges of fascism because of the stylistic choices that they made in their writing, both in the manifesto and in their other work. For instance, when Ransom writes that the attitude of the unreconstructed Southerner he has been describing 'does not constitute a danger to the Republic; distinctly it is not treasonable', it is difficult to judge exactly what tone he is adopting ([1930] 2006: 2). If his readers had not been previously been entertaining the idea that his ideas might be treasonable, they might very well do so now. Since several of the most prominent writers - Ransom, Tate, Warren, and Davidson - came from a background in which, as members of the Nashville Fugitive poetry group they paid such strict attention to selecting the mot juste, it is difficult to believe that they didn't select their words in I'll Take My Stand equally carefully (after all, they famously came to verbal blows over the manifesto's title). So the approach the Agrarians take is a dangerous one, but Brown and Lumpkin seem to be suggesting that it is not uncalculated, and instead represents a deliberate effort to appeal to a certain group or groups of people who might sympathise with their celebration of heritage and that tradition they encouraged the southerner to seize.

\section{The dangers of nostalgia and heritage - then and now}


This embrace of risk and deliberate reluctance to make clear entirely what they mean, especially around questions of violence, does indicate an irresponsibility on the part of the Agrarians. It suggests a willingness to create and rewrite a narrative about a partly imaginary or idealised past that sounds very much, as I've already indicated, like nostalgia, a term that Svetlana Boym notes is often used negatively. In a 2007 essay entitled 'Nostalgia and its Discontents', she quotes Michael Kammen, who claims: 'Nostalgia [...] is essentially history without guilt. Heritage is something that suffuses us with pride rather than shame'. Boym continues:

In this understanding, nostalgia is seen as an abdication of personal responsibility, a guilt-free homecoming, an ethical and aesthetic failure. Nostalgia produces subjective visions of afflicted imagination that tend to colonize the realm of politics, history, and everyday perception. (2007: 9)

As I have been arguing, the Agrarians used their own 'afflicted imagination' to embrace failure as an aesthetic and political strategy and - as Tate said explicitly - regarded failure as a mark of 'their deepest heritage' as Southerners. As a concept then, heritage is a slippery one, for the way that the Agrarians use it, whether in their language or in the stories they tell, is bound up with nostalgia ('history without guilt'), and even has the potential to do harm. To recall Benjamin, such devotion can be put at the service of extremism, with the aim to "make the continuum of history explode.'

Euan Hague and Edward H. Sebesta have outlined how ' $[\mathrm{t}]$ he Twelve Southerners mapped their struggle for agrarianism onto the battle for the Confederacy, and it is this source, as much as any other, that became the basis for late-twentieth-century neoConfederate reinterpretations of the Civil War, its legacy and a vision of the future' (2008: 28). Charting how the tenets of I'll Take My Stand came to represent an authentic Southern identity, Hague and Sebesta see much correspondence between the white supremacy promoted in the Agrarian writings and the racism, ethnic hatred and violent nationalism advanced by more recent neo-Confederate groups. In their explanation of how these contemporary groups are indebted to earlier conservative movements such as Agrarianism, they draw upon a 2002 interview with the then director of the League of the South, Jack Kershaw, in the League's magazine, Southern Patriot. (Kershaw was well known not just for his segregationist views but also his role as the attorney to James Earl Ray, the murderer of Dr. Martin Luther King Jr.) The interviewer, Ross Massey, apparently making reference to 
the teachings of I'll Take My Stand, asked Kershaw: 'Much of what made the South good is agrarian roots. Our population growth is out of control with Yankees and other foreign cultures moving in. What one thing can Southerners do to maintain our society?' Kershaw replied: ‘Arm yourselves' (2008: 33). After Kershaw's death in 2010, numerous obituaries pointed out that he had known the Fugitive poets when he was a student at Vanderbilt, though given he was born in 1913 and the Fugitives effectively disbanded in 1925, this claim seems questionable. Nevertheless, his answer to Massey's question suggests that he was at least a diligent reader of I'll Take My Stand, since it is an uncanny echo of Tate's answer to his own question in his essay in the Agrarian manifesto: 'How may the Southerner take hold of his Tradition? The answer is, by violence.' Here then we can see the lineage of the Agrarians being extended into contemporary neo-Confederacy, and the League of the South is recognised as one of the most prominent hate groups in America with a number of members arrested for violent acts at recent protests, including the 'Unite the Right' rally in 2017.

Conversations about Southern heritage in recent years have become inextricably bound up with new questions of violence and race. Hardly a day passes without discussion in local or national media or in state legislatures or city councils regarding Confederate symbols, whether those are the Confederate battle flag or monuments dedicated to figures associated with the Confederacy. With the events at Charlottesville in 2017, the association of neo-Confederacy with white supremacy became more complicated, and some neoConfederate voices, such as the Sons of the Confederate Veterans (SCV) and the United Daughters of the Confederacy (UDC) have found themselves losing control of the narrative about the Civil War that they had historically controlled and manipulated so successfully. Unconvincing it may have been as a slogan, but the 'heritage not hate' banner waved by neoConfederates, including the SCV and the UDC, did not seem to advocate violent action as a way of preserving that heritage. However, according to the Southern Poverty Law Center (SPLC), a non-profit organization that monitors and litigates against white supremacist groups,

[t]he bloody excesses on display at the Unite the Right rally in Charlottesville, Virginia, were not the first - nor will they be the last - incident of violence related to the unraveling of the Lost Cause narrative. As the appeal of neo-Confederate ideology and symbols wanes among the general American public, it is becoming much more deeply entrenched among all stripes of the far right. (2018) 
The SPLC identifies an irony: as the neo-Confederates apparently become more visible, so their core ideology, the Lost Cause, seems to be falling apart. As the SPLC rightly points out, there is a spectrum of neo-Confederate groups, and the problem for the more 'mainstream' neo-Confederates like the SCV and the UDC is that their platform is being stolen from underneath them by other, more explicitly white supremacist organizations such as the altright, the KKK, the League of the South, and Identity Dixie, and this may come at a serious cost for the coherence of the neo-Confederate cause.

When in a letter to Tate of 15 February 1927 Donald Davidson critiqued an early draft of 'Ode to the Confederate Dead' (then called an elegy), he remarked:

Wherever your poetry is out-and-out argumentative [...] I follow you all the way and am nearly ready to say you are at your best; when you deal with things themselves, the things become a ruin and a crackle like broken shards under your feet. The Confederate dead become a peg on which you hang an argument whose lines [...] leave me wondering why you wrote a poem on the subject at all, since in effect you say [...] that no poem can be written on such a subject. (Fain and Young (eds.) 1974: 186 , emphasis in original)

As neo-Confederate groups like the SCV and the UDC watch some of their monumental heritage 'become a ruin and crackle like broken shards under [their] feet', they also see their attempts at resistance compromised by an association with extreme right-wing groups for whom a Robert E. Lee statue in Charlottesville is not an issue of heritage but rather 'a peg on which [they] hang an argument' about a white ethnostate, and these more mainstream neoConfederates find themselves being left behind as critical discussions around whiteness become more and more a part of the debate. Just as the Agrarians struggled against the link that was made between them and fascism, so some neo-Confederates now find themselves grouped with extremists. As Graham Fairclough and others have suggested, 'heritage is no longer about the past but draws on the power of the past to produce the present and shape the future' (2008: 1). That 'immoderate past' that Tate identified nearly one hundred years ago continues to spill over into the present, but the identity of those who control how we represent that past is becoming less and less certain.

\section{References}


Anon (1930), 'Lee, We Are Here!', Macon Telegraph, September 29, Donald Grady

Davidson Papers, Special Collections, Jean and Alexander Heard Library, Vanderbilt University, Fugitives and Agrarians, Appendix C 1924-1936, Box 36, Folder 9.

Anon (2018), 'Neo-Confederate', SPLC Southern Poverty Law Center, https://www.splcenter.org/fighting-hate/extremist-files/ideology/neo-confederate. Accessed 26 April 2019.

Baudelaire, Charles ([1863] 2006, 'The Painter of Modern Life' in Selected Writings on Art and Literature (trans. P. E. Charvet), London: Penguin Books.

Benjamin, Walter ([1955] 1999), Illuminations (ed. Hannah Arendt and trans. Henry Zohn), London: Pimlico.

Blanchot, Maurice ([1980] 1995), The Writing of the Disaster (trans. Ann Smock), Lincoln: University of Nebraska Press.

Blight, David W. (2001), Race and Reunion: The Civil War in American Memory, Cambridge: Harvard University Press.

Boym, Svetlana (2007), 'Nostalgia and its Discontents', The Hedgehog Review, 9: 2, pp. 718.

Brown, Sterling, A. (1930), 'Unhistoric History', Journal of Negro History, 15: 2, pp. 134161.

Cook, Robert J. (2017), Civil War Memories: Contesting the Past in the United States since 1865, Baltimore: Johns Hopkins Press.

Davidson, Donald ([1934] 1966), 'Lee in the Mountains', in Poems, 1922-1961, Minneapolis: University of Minnesota Press.

— ([1959] 1966), 'Lines Written for Allen Tate on his Sixtieth Birthday', in Poems, 19221961, Minneapolis: University of Minnesota Press. 
Donaldson, Susan V. (2006), 'Introduction: The Southern Agrarians and Their Cultural Wars', in Twelve Southerners, ([1930] 2006), I'll Take My Stand: The South and the Agrarian Tradition, Baton Rouge: Louisiana State University Press, pp. ix-xl.

Fain, John Tyree and Young, Thomas Daniel (1974), The Literary Correspondence of Donald Davidson and Allen Tate, Athens: University of Georgia Press.

Fairclough, Graham, Harrison, Rodney, Jameson, Jr., John H. and Schofield, John (2008), 'Introduction: Heritage, Memory and Modernity', in Graham Fairclough, Rodney Harrison, John H. Jameson, Jr., and John Schofield (ed.), The Heritage Reader, Abingdon: Routledge, pp. 1-12.

Faulkner, William ([1948] 1964), Intruder in the Dust, London: Penguin.

Gray, Richard (1997), Writing the South: Ideas of An American Region, Baton Rouge and London: Louisiana State University Press.

Habermas, Jürgen ([1985] 1987), The Philosophical Discourse of Modernity: Twelve Lectures (trans. Frederick Lawrence), Cambridge: Polity Press.

Hague, Euan, Sebesta, Edward H., and Beirich, Heidi (2008), 'Introduction: NeoConfederacy and the New Dixie Manifesto', in Euan Hague, Edward H. Sebesta, and Heidi Beirich (eds), Neo-Confederacy: A Critical Introduction, Austin: University of Texas Press, pp. 1-19.

Hague, Euan, and Sebesta, Edward H. (2008), 'Neo-Confederacy and Its Conservative Ancestry', in Euan Hague, Edward H. Sebesta, and Heidi Beirich (eds), NeoConfederacy: A Critical Introduction, Austin: University of Texas Press, pp. 23-49.

Halbwachs, Maurice, ([1941, 1952] 1992) On Collective Memory (ed. and trans. Lewis A. Coser), Chicago and London: University of Chicago Press.

Hammer, Langdon, and Weber, Brom (1997), O My Land, My Friends: The Selected Letters 
of Hart Crane, New York and London: Four Walls Eight Windows.

Hook, Andrew (2004), 'Fugitives and Agrarians', in Richard Gray and Owen Robinson, (eds.), A Companion to the Literature and Culture of the American South, Oxford: Blackwell Publishing, pp. 420-435.

Lumpkin, Grace (1936), 'I Want a King', FIGHT Against War and Fascism, III: 4, February 1936, quoted in 'Fascism and the Southern Agrarians', The New Republic, May 27, 1936, LXXXVII: 1121, pp. 75-76.

Lytle, Andrew (1980), ‘A Journey South', The Kentucky Review, 1: 3, pp. 3-10.

Mencken, H.L. (1931), 'Uprising in the Confederacy', American Mercury, March, pp. 379381.

Milton, George Fort (1930), 'The Young Confederates', Chattanooga News, September 3, Donald Grady Davidson Papers, Special Collections, Jean and Alexander Heard Library, Vanderbilt University, Fugitives and Agrarians, Appendix C 1924-1936, Box 36, Folder 9.

Murphy, Paul V. (2001), The Rebuke of History: The Southern Agrarians and American Conservative Thought, Chapel Hill and London: University of North Carolina Press.

O'Brien, Michael (1988), Rethinking the South: Essays in Intellectual History, Baltimore and London: The Johns Hopkins University Press.

Pryor, Elizabeth Brown ([2007] 2008) Reading the Man: A Portrait of Robert E. Lee Through His Private Letters, London: Penguin Books, 2008.

Southerners, Twelve ([1930] 2006), I'll Take My Stand: The South and the Agrarian Tradition, Baton Rouge: Louisiana State University Press.

Tate, Allen, 'Ode to the Confederate Dead' ([1930] 2007), in Collected Poems, 1919-1976, New York: Farrar, Straus and Giroux. 
_ (1936) Open letter, To Grace Lumpkin, in 'Fascism and the Southern Agrarians', The New Republic, May 27, 1936, LXXXVII: 1121, pp. 75-76.

_ (undated [1963]), 'The Battle of Gettysburg', Allen Tate Papers, 1921-1979, Princeton University Library, Department of Rare Books and Special Collections, Subseries 1C: Essays by Allen Tate, 1925-1965, Box 3, Folder 7.

_ (1963), 'The Battle of Gettysburg: Why It Was Fought', Carleton Miscellany, IV: 3, pp. 32-45.

— (1970), Essays of Four Decades, London: Oxford University Press.

—_([1977] 2007), Collected Poems, 1919-1976, New York: Farrar, Straus and Giroux.

Underwood, Thomas A. (2000), Allen Tate: Orphan of the South, Princeton: Princeton University Press.

Wilson, Charles Reagan ([1980] 2009), Baptized in Blood: The Religion of the Lost Cause, 1865-1920, Athens and London: University of Georgia Press.

Wilson, Janelle L. ([2005] 2014), Nostalgia: Sanctuary of Meaning, Minneapolis: Minnesota Libraries Publishing.

Young, Thomas Daniel, and Hindle, John J. (eds.) (1981), The Republic of Letters in America: The Correspondence of John Peale Bishop \& Allen Tate, Lexington: University Press of Kentucky. 